\title{
Damian NOREMBERG
}

Firma neoPR

\section{Kampania negatywna, czy nieistniejący „czarny” PR, jako metody dyskredytowania przeciwnika politycznego}

\begin{abstract}
Czarny” PR to pojęcie bardzo często pojawiające się w mediach. Termin ten wszedł do naszego języka po 1989 roku, czyli po transfor"macji ustrojowej. Choć działania z zakresu „czarnego" PR można zauważyć już dużo wcześniej, choćby kampania skierowana przeciwko Lechowi Wałęsie, który został nominowany do pokojowej Nagrody Nobla, to wyrażenie to „spowszedniało” stosunkowo niedawno. Czym zatem jest „czarny” PR? Moim zdaniem jest niczym. Coś takiego nie istnieje! Fundamentem działań Public Relations jest prawda, to podstawowa zasada pracy w tym zawodzie. Osobiście, nie wyobrażam sobie, że ktoś, kto posługuje się kłamstwem lub „półprawdą” może nazywać się specjalistą PR, Choć pojawiają się definicje „czarnego” PR, np. w wikipedii - ,potocznie czarny pijar od czytanego niestarannie z angielska skrótu wyrazów public relations ,pi-ar”, antyreklama, negatywna kampania wyborcza - oznacza system metod, działań bądź posunięć propagandowych, ale przede wszystkim manipulacyjnych, prowadzących do zdyskredytowania przeciwnika (zwykle polityka lub firmy) w oczach opinii publicznej celem zdobycia jej przychylności (zwykle elektoratu lub klientów). Aby tego dokonać, stosuje się między innymi przecieki prasowe (prawdziwe lub prawdopodobne), które przedstawiają przeciwnika w niekorzystnym świetle".

„Czarny” PR to „działalność dywersyjna, sabotaż, dezinformacja, działania ukryte, kamuflaż, demarketing, oszustwa marketingowe, czarna reklama, propaganda, wojna psychologiczna" - te właśnie zjawiska, według Jerzego Olędzkiego, odnoszą się do tego określenia ${ }^{2}$.

1 http://pl.wikipedia.org/wiki/Czarny_PR, dostęp: 10.05.2011.

2 J. Olędzki, Czarne sztuczki, propaganda i brudny PR, referat wygłoszony na III Kongresie PR w Wyższej Szkole Informatyki i Zarządzania w Rzeszowie, kwiecień 2004, s. 2.
\end{abstract}


Prawdziwym problemem takich działań jest to, że fałszywe informacje są pożywką dla mediów i dość długo utrzymują się w świadomości publicznej. Informacje przekazywane przez media są najważniejszym czynnikiem wpływającym na decyzje wyborcze społeczeństwa - kształtują postawy wyborców i polityków. Media [...] są naturalnym źródłem informacji, na podstawie których budowana jest decyzja wyborcza ${ }^{3}$. Dlaczego jest to problem dla osób zajmujących się budowaniem strategii kampanii wyborczych? Odpowiedź jest także prosta, z kłamstwem jest bardzo trudno walczyć, jeszcze trudniejsze jest to w przypadku tzw. półprawdy, kiedy część informacji jest prawdziwa, ale podana w taki sposób, aby zmienić jej znaczenie. Każdy z nas zna siłę plotki i wie, że jej zdementowanie nie jest łatwe. Niestety, plotka weszła w zakres języka komunikacji politycznej i bardzo często jest wykorzystywana podczas kampanii wyborczej. Takim przykładem jest głośna sprawa z kampanii prezydenckiej, gdzie wypomniano Donaldowi Tuskowi, że jego dziadek był członkiem Wermachtu. 16 października 2005 r. Angora publikuje wywiad Katarzyny Pastuszko z Jackiem Kurskim:

„K. Pastuszko: Zaczyna pan wyciagać haki na drugą turę?

J. Kurski: Nie. Mówię prawdę.

K. Pastuszko: A czy to prawda, że jednym z planowanych przez was haków było ubranie Donalda Tuska w mundur żołnierza Wehrmachtu? J. Kurski: To obrzydliwe. To, że w jego domu mówiło się po niemiecku, nie oznacza, że trzeba go przebierać w mundur.

K. Pastuszko: Po niemiecku?

J. Kurski: Rodzice Tuska byli gdańszczanami i mówili po niemiecku. Pisał o tym wiele razy w swoich książkach. Jest natomiast półmrok niedomówień i tajemniczości na temat dziadka Donalda Tuska. Sądzę, że w jego interesie leży wyjaśnienie tej kwestii. W przypadku wyborów prezydenckich Polacy mają prawo wiedzieć wszystko o kandydacie.

K. Pastuszko: Rozumiem, że pan wie?

J. Kurski: Niczego nie wiem na pewno. Poważne źródła na Pomorzu mówią, że dziadek Tuska zgłosił się na ochotnika do Wehrmachtu. Na Pomorzu zdarzało się często wcielanie do Wehrmachtu, ale siłą. Cokolwiek było z jego dziadkiem nie winię za to Donalda Tuska. Winię go jedynie za tolerowanie plotek na ten temat. Powinien albo zaprzeczyć,

3 M. Mazur, Marketing polityczny. Wyczerpujacy przeglad technik i metod stosowanych $w$ kampanii wyborczej, Warszawa 2002, s. 281. 
albo potwierdzić, a nie milczeć. To już nie jest jego prywatna sprawa. Tusk nie kandyduje na prezydenta Sopotu, tylko prezydenta Polski”"

Później okazało się, że przodek kandydata był wcielony do niemieckiej armii przymusowo. Jednak informacja o „dziadku z Wehrmachtu” odbiła się szerokim echem w mediach i była na ustach całej Polski. Sama wypowiedź Jacka Kurskiego, że w domu Tuska mówiono po niemiecku, choć nie wprost, jest informacją, która miała dyskredytować Tuska, jako „prawdziwego” Polaka. Po tej wypowiedzi w Internecie pojawiły się grafiki pokazujące D. Tuska w niemieckim mundurze, z podpisem: „Słodka tajemnica ujawniona - Tusku w mundurze dziadunia” i wieloma innymi, obraźliwymi opiniami.

Sztandarowym przykładem prowadzenia brudnej kampanii wyborczej jest Stanisław Tymiński, który straszył ,czarną teczką", w której miał rzekomo materiały oczerniające innych kandydatów, a przede wszystkim Lecha Wałęsę. Jak sam przyznał później, większość z nich to były podrobione dokumenty opatrzone pieczątką z kartofla ${ }^{5}$.

„Czarny” PR powstał dużo wcześniej, niż sama nauka o Public Relations. Przykład tego, jak skuteczny może być „,czarny” PR można się przekonać dzięki J. Olędzkiemu, który w 2004 roku podczas Kongresu PR w Wyższej Szkole Zarządzania i Informatyki w Rzeszowie zacytował Dmitrija Babicha (przedruk

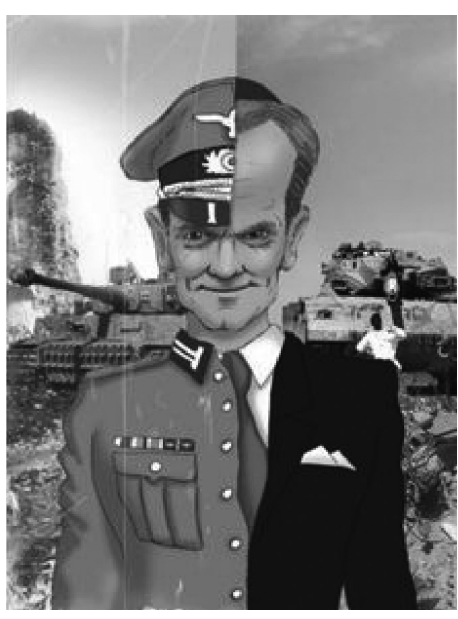

Źródło: http://www.spieprzajdziadu.com/ muzeum/index.php?title=Antologia_poezji_wolskiej, dostęp: 10.05.2011. fragmentu tekstu z: „Gazeta Wyborcza” z dnia 6-7 grudnia 2003 r.) „Istnieje legenda o skapsstwie Szkotów. Są nawet kawały o Poznaniakach vel Krakusach, których wygnano ze Szkocji za nadmierne skąpstwo. Nie ma jednak racjonalnych przesłanek do twierdzenia, by Szkoci byli bardziej skąpi od Holendrów lub Francuzów. Kiedy w roku 1603 na tron angielski wstąpił Jakub I z dynastii

4 http://beniowski.salon24.pl/176778,dziadek-z-wehrmachtu-jak-bylo-naprawde, dostęp: 10.05.2011.

${ }^{5}$ http://wiadomosci.gazeta.pl/Wiadomosci/1,80708,5854089,Tyminski_W_czarnej_teczce_byly_nieudolne_podrobki.htm, dostęp: 10.05.2011. 
Stuartów, do tej pory panujący w Szkocji jako Jakub VI, przywiódł ze sobą do Londynu zaufanych Szkotów, ubogich - w porównaniu z zamożnymi panami angielskimi - przeto i bardziej od nich wstrzemięźliwych w wydatkach. Wtedy to rozrzutni Anglicy ukuli serię złośliwych dowcipów o skapstwie szkockich rywali do królewskiej łaski. Ten «czarny PR» przetrwał 400 lat!” (Źródło: „Gazeta Bankowa” nr 39 z 29 września 2003 r.) ${ }^{6}$.

Najlepsze, moim zdaniem, określenie dla „czarnego” PR znalazła Ewa Hope: „W przypadku public relations używa się przymiotnika «czarny» na określenie wynaturzonej, karykaturalnej formy działań z zakresu komunikacji wykorzystujących często techniki manipulacji, mających różne cele - począwszy od zniszczenia konkurencji, poprzez uzyskanie różnych profitów, a skończywszy na takich subtelnościach jak odwrócenie uwagi i mediów i opinii publicznej, z wykorzystaniem różnych technik, metod"7.

Jak zatem walczyć z „czarnym” PR. Najlepszym lekarstwem jest prawda, która według powiedzenia „obroni się sama”. Nie można nie reagować na kłamstwa rozpowszechniane na temat kandydata, z którym pracujemy, naszym obowiązkiem jest dbanie o jego wizerunek. Jednak walka z kłamstwem jest bardzo trudna, czasem niestety, należy po prostu skierować sprawę do sądu i czekać na jej wyjaśnienie. Jeśli dzieje się to w czasie oficjalnej kampanii wyborczej na rozstrzygnięcie czekamy krótko jednak, kiedy działania marketingowe rozpoczęte są wcześniej, czas oczekiwania na wyrok sądu może się wydłużyć. Jeśli posiadamy informacje, najlepiej dowody, że oszczerstwa kierowane w naszego kandydata są kłamstwem, należy je upublicznić, używając w tym celu każdego dostępnego środka przekazu. Najlepiej w tym celu wykorzystać telewizję, jeśli jednak nie możemy skorzystać z jej usług, na zasadzie materiału dziennikarskiego, kolejnym doskonałym źródłem komunikacji jest Internet. Oficjalna strona kandydata, page na Facebook.com, czy nagranie krótkiej rozmowy i umieszczenie jej w portalu youtube.com są skutecznymi metodami. Pamiętajmy jednak, że muszą to być materiały wiarygodne, potwierdzone przez nas.

„To głównie «dzięki» polityce PR kojarzy się częściej z kłamstwem i manipulacją niż - jak chcieliby sami piarowcy - z dialogiem i komu-

6 J. Olędzki, Referat na III Kongresie PR w Wyższej Szkole Informatyki i Zarzqdzania w Rzeszowie, kwiecień 2004, s. 9.

7 E. Hope, Z zagadnień filozofii zarzqdzania i etyki biznesu, Gdańsk 2005, za: https:/www.studiumpr.pl:448/node/150, dostęp: 10.05.2011. 
nikacją z otoczeniem. - Sam termin PR nabiera takiego znaczenia jak wcześniej «czarny» PR - stwierdził Adam Łaszyn, prezes zarządu Alert Media Communications, doradca medialny PO. A Wiesław Gałązka z Dolnośląskiej Szkoły Wyższej we Wrocławiu podkreślał, że termin 'zmiana wizerunku', np. partii, jest często interpretowany, jako sygnał, że «będziemy was okłamywać lepiej niż dotąd»” („Nowiny”, 27.04.2009).

Politycy „uwielbiają” używać pojęcia „pijar” w kontekście działań przeciwników politycznych. Bardzo często wszystkie informacje przekazywane przez polityków są nazywane przez przeciwników „zagrywkami Pijarowskimi”. Najczęściej to pojęcie znajdowało się w ustach Jacka Kurskiego.

Tabela 1

Udzial procentowy publikacji prasowych na temat poszczególnych partii politycznych w kontekście działań PR

\begin{tabular}{|l|c||}
\hline \multicolumn{1}{|c|}{ Partia } & \% \\
\hline PO & 59,77 \\
\hline PiS & 33,14 \\
\hline SLD & 3,12 \\
\hline PSL & 2,55 \\
\hline Libertas & 0,57 \\
\hline Centrolewica & 0,28 \\
\hline LPR & 0,28 \\
\hline SdPl & 0,28 \\
\hline Suma & 100,00 \\
\hline
\end{tabular}

Źródło: PR w ustach polityków. Raport przygotowany na zlecenie Związku Firm Public Relations - styczeń-maj 2009.

Jacek Kurski wielokrotnie używał słowa PR w kontekście działań przeciwników politycznych $\mathrm{w}$ różnych kontekstach swoich wypowiedzi. Jego komentarze są związane z działalnością rządu, przede wszystkim w ten sposób komentuje wszystkie działania, które w jakikolwiek sposób odniosły sukces. Najciekawsze wypowiedzi polityka zostały zebrane w raporcie „PR w ustach polityków”. Raport ten został przygotowany na zlecenie Związku Firm Public Relations.

Zebrane niżej wypowiedzi pochodzą z 2009 roku i zostały wypowiedziane w przeciągu pięciu miesięcy: styczeń-maj 2009 r. 
Wykres 1. Liczba publikacji z wypowiedziami poszczególnych polityków na temat PE

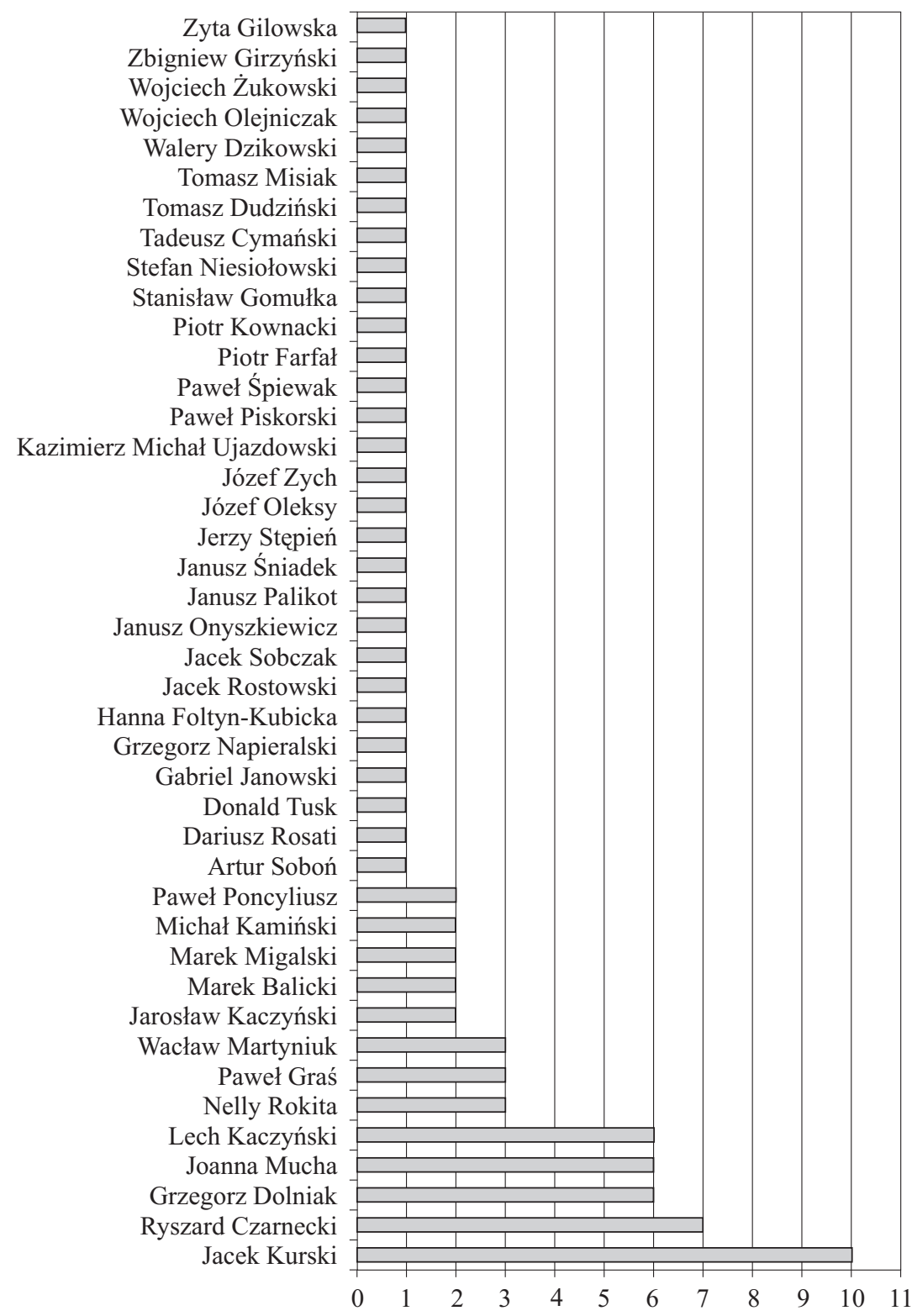

Źródło: PR w ustach polityków. Raport przygotowany na zlecenie Związku Firm Public Relations - styczeń-maj 2009, dostęp: 10.05.2011. 


\begin{tabular}{|c|c|c|c|c|c|}
\hline $\begin{array}{l}\text { Imię } \\
\text { i naz- } \\
\text { wisko }\end{array}$ & $\begin{array}{l}\text { Przyna- } \\
\text { leżność } \\
\text { partyjna }\end{array}$ & Cytat & Kontekst & Medium & Data \\
\hline $\begin{array}{l}\text { Jacek } \\
\text { Kurski }\end{array}$ & PiS & $\begin{array}{l}\text { Premier używa stoczniowców jako } \\
\text { mięsa armatniego w swoich PR-ow- } \\
\text { skich zagrywkach }\end{array}$ & Manipulacja & GW & 19.05 \\
\hline $\begin{array}{l}\text { Jacek } \\
\text { Kurski }\end{array}$ & PiS & $\begin{array}{l}\text { Kastracja pedofilów. Czysto PR-ow- } \\
\text { ski strzał }\end{array}$ & Populizm & Dziennik & 2.05 \\
\hline $\begin{array}{l}\text { Jacek } \\
\text { Kurski }\end{array}$ & PiS & $\begin{array}{l}\text { W rozmowie z „Dziennikiem” pomysł } \\
\text { prezydenta Sopotu nazywa PR-owską za- } \\
\text { grywką. - To człowiek, który stoi pod za- } \\
\text { rzutami kryminalnymi i próbuje przejąc } \\
\text { inicjatywę polityczną, uciec do przodu }\end{array}$ & Manipulacja & Dziennik & 3.05 \\
\hline $\begin{array}{l}\text { Jacek } \\
\text { Kurski }\end{array}$ & PiS & $\begin{array}{l}\text { Po raz pierwszy mamy na taką skalę } \\
\text { zjawisko zastępowania realnego rządze- } \\
\text { nia matriksem i PR-em }\end{array}$ & Manipulacja & GW & 26.01 \\
\hline $\begin{array}{l}\text { Jacek } \\
\text { Kurski }\end{array}$ & PiS & $\begin{array}{l}\text { Gabinet Tuska zastępuje realne } \\
\text { rządzenie matriksem i PR-em }\end{array}$ & Manipulacja & Przekrój & 22.01 \\
\hline $\begin{array}{l}\text { Jacek } \\
\text { Kurski }\end{array}$ & PiS & $\begin{array}{l}\text { Gołym okiem widać, że premier, de- } \\
\text { cydując o odejściu ministra, kierował } \\
\text { się PR-em }\end{array}$ & Manipulacja & $\begin{array}{l}\text { Echo } \\
\text { Dnia }\end{array}$ & 21.01 \\
\hline $\begin{array}{l}\text { Jacek } \\
\text { Kurski }\end{array}$ & PiS & $\begin{array}{l}\text { Gołym okiem widać, że kierował się } \\
\text { PR-em, ale jeśli PR ma dobre skutki, } \\
\text { to przyjmujemy to z dobrodziejstwem } \\
\text { inwentarza }\end{array}$ & Manipulacja & Nowości & 21.01 \\
\hline
\end{tabular}

Źródło: PR w ustach polityków. Raport przygotowany na zlecenie Związku Firm Public Relations - styczeń-maj 2009.

\section{Inne przykłady „Czarnego PR”}

Jednym z pierwszych przykładów zastosowania narzędzi brudnej kampanii wyborczej była kampania Stanisława Tymińskiego. Tymiński przyleciał do Polski z Peru i kandydował na Urząd Prezydenta RP. Niespodziewanie dostał się do drugiej tury wyborów, pokonując m.in. ówczesnego premiera Tadeusza Mazowieckiego. W walce z Lechem Wałęsą posłużył się kłamstwem na temat rzekomej współpracy Wałęsy ze służbami bezpieczeństwa. Twierdził też, że ma na to dokumenty. Posługiwał się wtedy gadżetem - czarną teczką, w której, znajdowały się dokumenty potwierdzające współpracę Wałęsy. Z czarną teczką Tymiński pokazywał się wszędzie. Okazało się, że w teczce znajdowały się „,nieudolnie podrobione dokumenty opatrzone pieczątką z kartofla"».

8 http://wiadomosci.gazeta.pl/Wiadomosci/1,80708,5854089,Tyminski_W_czarnej_teczce_byly_nieudolne_podrobki.html, dostęp: 10.05.2011. 
Podobnym przykładem można nazwać wspomnianą już tu insynuację Jacka Kurskiego, który chciał wprowadzić w błąd opinię publiczną twierdząc, że dziadek Donalda Tuska jako ochotnik wstapił do Wehrmachtu.

Jednym z mistrzów prowadzenia brudnej kampanii wyborczej, także permanentnej jest Janusz Palikot, obecnie lider ugrupowania Ruch Poparcia Palikota, a wcześniej poseł z ramienia Platformy Obywatelskiej. Klasycznym przykładem manipulacji jest insynuacja, że Lech Kaczyński - Prezydent RP ma problemy z alkoholem. Taki tekst wpisał na swoim blogu Palikot ${ }^{9}$. Wpis ten odbił się szerokim echem w mediach ogólnopolskich i spowodował fale dyskusji dotyczącej etyki polityków. Sam Palikot nie poprzestał na tym stwierdzeniu, insynuował także, że Jarosław Kaczyński ma skłonności homoseksualne. Wypowiedź taka została zamieszczona m.in. w tabloidzie „Fakt”: „Myślałem raczej, że okaże się, iż Jarosław Kaczyński jest hetero, Mariusz Kamiński propaństwowcem, a Lech Kaczyński abstynentem niż to, że ja zostanę wiceszefem Klubu PO!"

Brudne kampanie wyborcze nie są zarezerwowane tylko dla ogólnopolskich sporach politycznych. Z przykładami kłamstw i manipulacji możemy się spotkać także przy wyborach samorządowych. Mam wrażenie, że właśnie tutaj najłatwiej jest rzucić oszczerstwa na przeciwników politycznych. Sprawy te dotyczą lokalnego środowiska, miejsca, gdzie znają się lepiej, mogą rozpoznać się na ulicy. Jednym z przykładów jest ostatnia kampania samorządowa, gdzie zarzucono kandydatce na prezydenta miasta, ubiegającej się o reelekcję, że swoje niepełnosprawne dziecko zamknęła w ośrodku, a teraz podczas kampanii przywiozła i pokazuje się z nim publicznie, żeby wszyscy wiedzieli, że jest dobrą matką.

\section{Kampania negatywna}

Dla wielu osób zajmujących się tworzeniem kampanii termin ten jest, niestety, równoznaczny z kampanią brudna, czy „,czarnym” PR. Pojęcia te są z gruntu rozbieżne. Kampania negatywna opiera się na prawdzie, nie ma tam miejsca na insynuacje, manipulacje, spinning, czy inne metody dyskredytowania przeciwnika za pomocą kłamstwa. Oczywiście, kampania negatywna ma pejoratywny przekaz, ale jest to przekaz zgodny z prawda,

9 http://palikot.blog.onet.pl/2,ID282457565,index.html, dostęp: 10.05.2011.

$10 \mathrm{http}: / / w w w . f a k t . p l / P a l i k o t-J a r o s l a w-g e j-a-L e c h-a l k o h o l i k-$,artykuly,55442,1.html , dostęp: 10.05.2011. 
przekazywane są prawdziwe informacje dotyczące sposobu zachowania kandydata czy ugrupowania, te negatywne przykłady są udokumentowane. Najczęściej odbywa się ona poprzez atak na poglądy, przekonania, jego zachowanie lub cechy osobowe ${ }^{11}$. Atak taki może być przypomnieniem głosowania polityka nad kontrowersyjną ustawą lub jego zachowanie podczas konkretnej uroczystości. Osobiście nie jestem zwolennikiem podawania do publicznej wiadomości informacji z życia prywatnego kontrkandydatów, ani puszczania przecieków na ten temat do mediów, choć jest to jeden ze sposobów skutecznego nadwyrężenia wizerunku kandydata.

Negatywna kampania wyborcza może przybierać kilka form. Reklama negatywna sensu stricte ma za zadanie pokazać konkurenta w negatywnym świetle. Jej celem jest stworzenie nieatrakcyjnego i niepożądanego wizerunku przeciwnika politycznego. Reklamy negatywne można podzielić także na dwa inne podgatunki: reklama problemowa oraz reklama wizerunkowa. Kampanie negatywne problemowe (negative issue advertising) w negatywnym świetle odnosi się do stanowiska, które przeciwnik zajmuje w sprawach trudnych i kontrowersyjnych. Zawiera często informacje na temat dokonań politycznych przeciwnika, jego poparciu lub braku poparcia dla określonych ustaw ${ }^{12}$. Negatywna reklama wizerunkowa (negative image advertising) negatywnie odnosi się do cech charakteru przeciwnika politycznego. Zawiera bardzo często informacje na temat stanu zdrowia, życia osobistego, przeszłości kryminalnej, a także jego rodziny i powiązań z różnymi grupami społecznymi. Reklama negatywna wizerunkowa może być podzielona na kilka podgrup:

- reklama atakująca, jak określa ją Gronbeck - napastnicza zawiera jednostronny atak na przeciwnika politycznego. Ma skupić uwagę wyborcy na słabych cechach przeciwnika, eechach osobowych oraz decyzjach politycznych;

- reklama porównawcza lub kontrastująca ma za zadanie ukazać przeciwnika politycznego jako gorszego, słabiej przygotowanego, ma przybliżyć poglądy i postawy tak, aby wyborca miał jasne porównanie z kandydaturą sponsora reklamy;

- reklama sugerująca porównanie - jest przekazem jednostronnym, który nie wskazuje bezpośrednio konkurenta politycznego ${ }^{13}$.

11 S. Trzeciak, Kampania wyborcza. Strategia sukcesu, Poznań 2002, s. 197.

12 W. Cwalina, A. Falkowski, Marketing polityczny. Perspektywa psychologiczna, Gdańsk 2006, s. 480.

13 Ibidem, s. 481. 
Reklama negatywna została zastosowana przez sztab wyborczy Mariana Krzaklewskiego w 2000 roku, gdzie sztab wyborczy przestawił spot telewizyjny „Incydent kaliski”. Reklama przestawiała Aleksandra Kwaśniewskiego, który na lotnisku w Kaliszu żartuje z gestów Jana Pawła II. Jego minister - Marek Siwiec - Szef Biura Bezpieczeństwa Narodowego wychodząc ze śmigłowca kreśli znak krzyża. A. Kwaśniewski pyta, „Czy minister Siwiec pocałował już ziemię kaliską?’. Po chwili Siwiec klęka i całuje ziemię. „Pobłogosław” - dodał prezydent Kwaśniewski.

Kampania negatywna może mieć także charakter humorystyczny. Mieliśmy takie przykłady podczas ostatniej kampanii wyborczej do parlamentu oraz w kampanii samorządowej. Bardzo często ataki takie odbywają się w Internecie, który jest obecnie najszybszym sposobem rozpowszechniania informacji. Elementem krytyki w kampanii negatywnej może być także wizerunek kandydata, zwłaszcza, jeśli jest on mocno zniekształcony. Takiego ataku mógł spodziewać się kandydat na urząd prezydenta Rzeszowa, Tadeusza Ferenca. Gazeta „Super Nowości" nie kryje swoich poglądów na temat prezydenta, który ubiega się o reelekcję. Wprost mówią o nim, że jest złym gospodarzem oraz pokazują jego zdjęcie zamieszczone na materiałach wyborczych w porównaniu $\mathrm{z}$ fotografią, którą prawdopodobnie sami wykonali. Informację o tym można znaleźć w Internecie na stronie wydawnictwa.
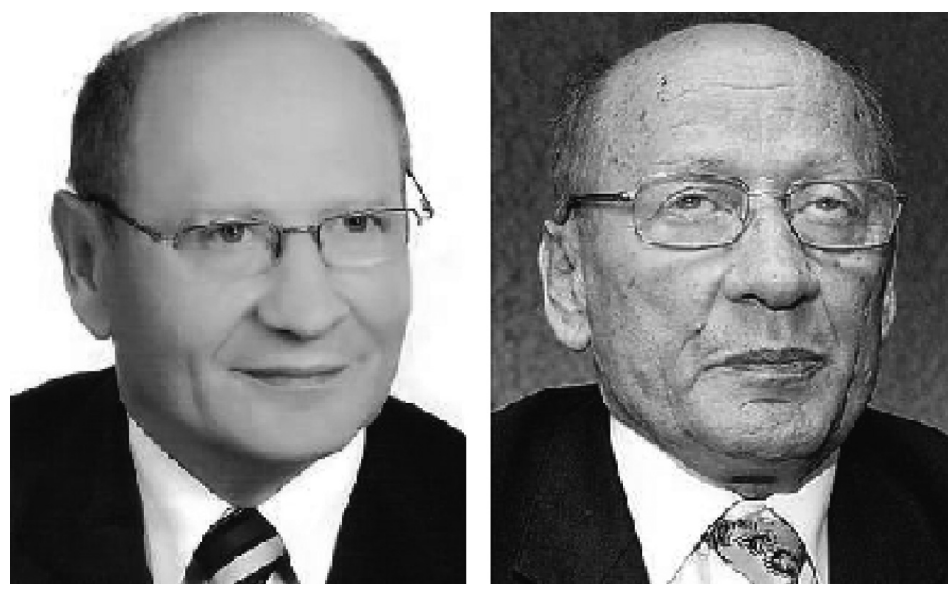

Źródło: http://supernowosci24.pl/obalamy-mit-ferenca-jako-dobrego-gospodarza/, dostęp: 10.05.2011.

Podobna sytuacja dotyczyła obecnej prezydent Łodzi Hanny Zdanowskiej, której porównanie wizerunku „odmłodzonej” kandydat 
$\mathrm{z}$ innym zdjęciem było umieszczone $\mathrm{w}$ Internecie oraz na plakatach w Lodzi.

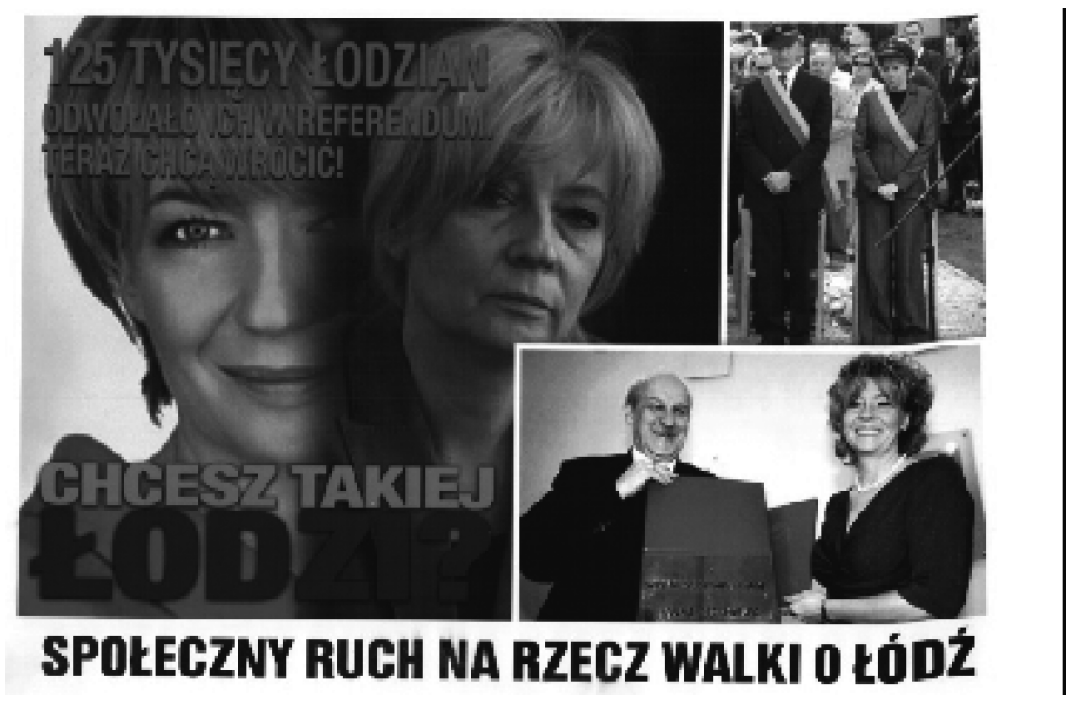

Źródło: http://www.skupienski.nazwa.pl/blog/wp-content/uploads/2010/12/hz1.jpg, dostęp: 10.05.2011.

Zbyt mocne wygładzenie wizerunku zawsze jest obiektem kpin i powodem ataku konkurencji. Zadaniem sztabu jest wybór takich zdjęć, na których kandydat będzie wyglądać dobrze, ale nie będą one przesadnie wygładzone, a kandydat odmłodzony. Podczas prowadzenia kampanii permanentnej, kiedy zależy nam na stałym utrzymaniu dobrego wizerunku sponsora warto mieć kilka przygotowanych, dobrych zdjęć, które chcemy, aby były przedstawiane w mediach. Nie mogą to być jednak zdjęcia nieaktualne, niemające wspólnych cech z obecnym, fizycznym wizerunkiem sponsora.

Negatywna, humorystyczna reklama banerowa jest często wykorzystywana w kampanii wyborczej. Jej przykłady można znaleźć w Internecie. Bardzo często nie mamy jednak jasnego przekazu, kto jest sponsorem tej reklamy. Bardzo często odnosi się ona do haseł, stylistyki materiałów wyborczych partii lub organizacji.

Jednym z takich przykładów jest reklama z wyborów samorządowych w 2010 roku. W mojej ocenie dość niefortunne hasło wyborcze PO stało się wielokrotnie obiektem kpin i żartów ugrupowań konkurencyjnych. Poniżej jeden z przykładów: 


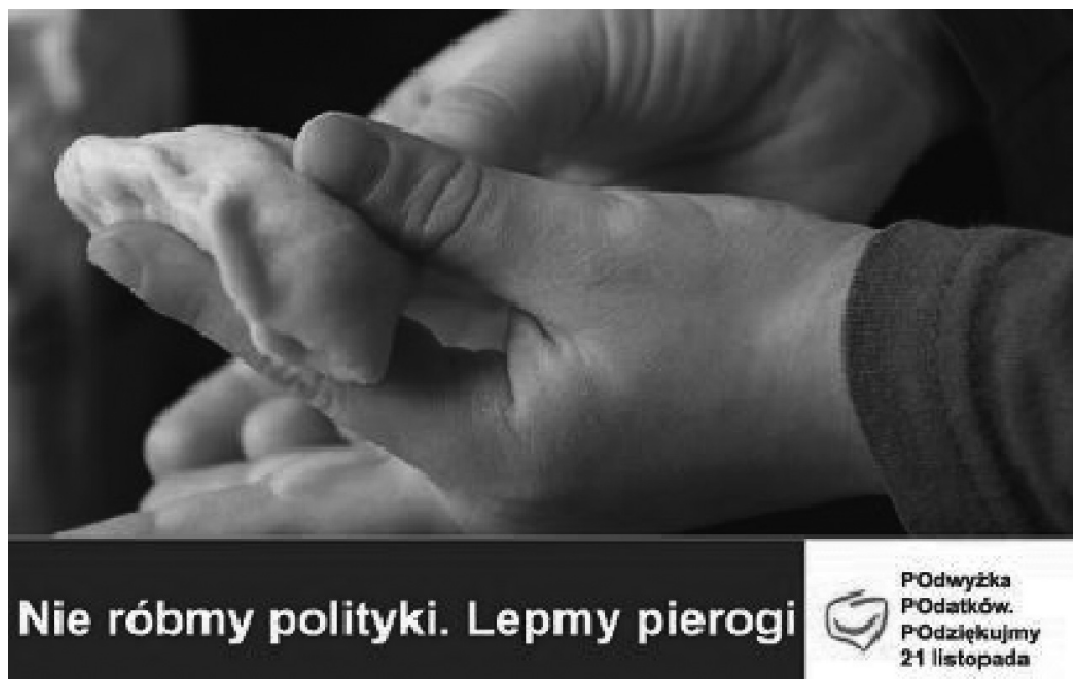

Źródło: http://www.wykop.pl/m/artykul/514597/nie-robmy-polityki-lepmy-pierogi/, dostęp: 10.05.2011.

Hasło „Nie róbmy polityki...” nie było najlepszym rozwiązaniem dla PO. Wiele miast nie przyjęło tego sloganu i posługiwało się własnymi hasłami wyborczymi.

Kolejnym przykładem wykorzystania hasła wyborczego przy konstruowaniu reklamy negatywnej jest poniższy baner umieszczony w Internecie. Posłanka PO Beata Sawicka została oskarżona o korupcję.
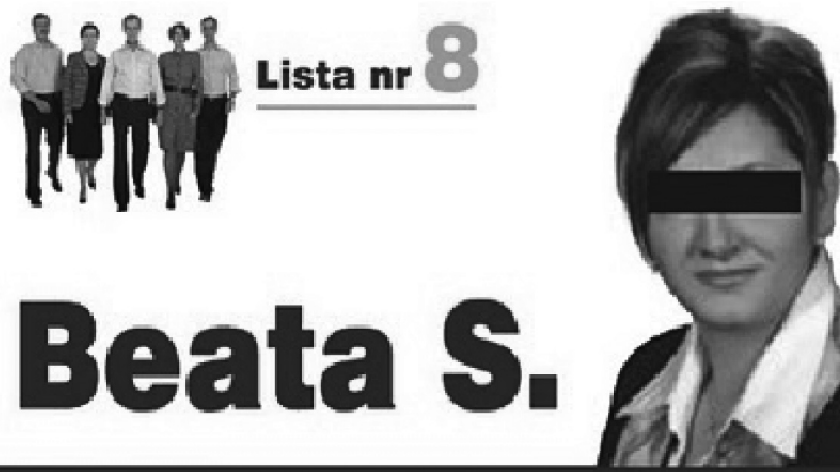

Biflomba By siedzialo się lepiej. Wszystkim!

Źródło: http://lista-obecnosci.blogspot.com/2007_09_30_archive.html, dostęp: 10.05.2011. 
I kolejny przykład kampanii negatywnej skierowanej przeciwko Platformie Obywatelskiej.

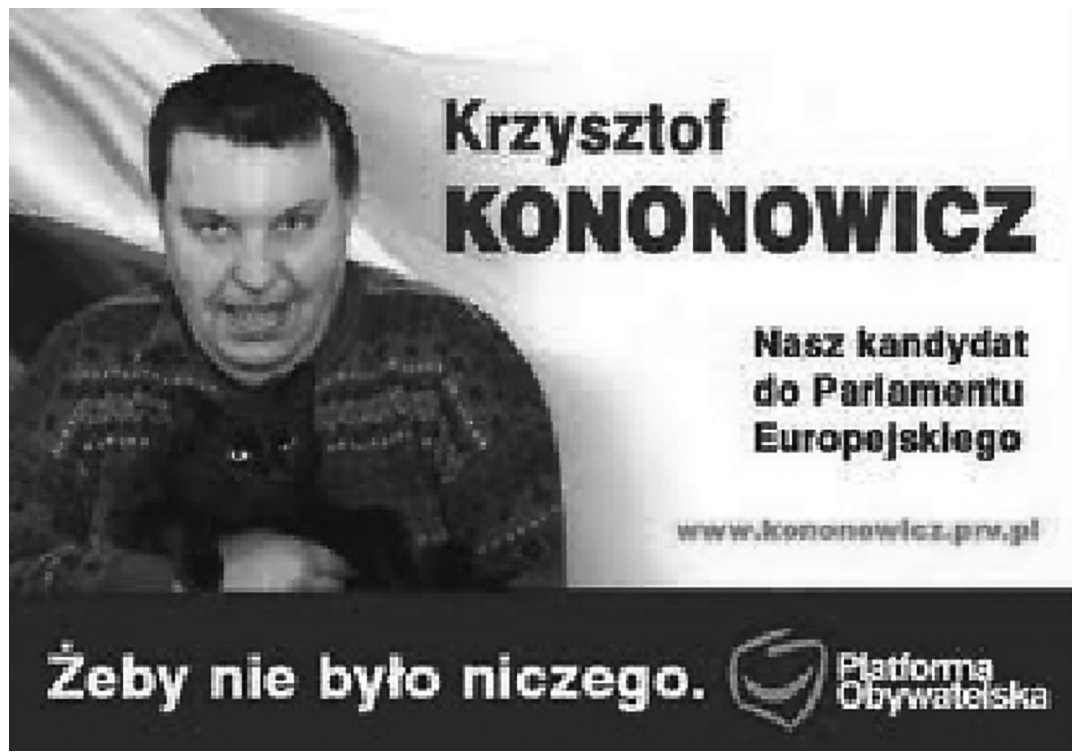

Źródło: http://yarrok.blogspot.com/2009/03/kolejny-eurowyborczy-hit-platformy.html, dostęp: 10.05.2011.

W tej reklamie wykorzystano wizerunek Krzysztofa Kononowicza, kandydata na Prezydenta Białegostoku w wyborach samorządowych w 2006 roku.

\section{Reagowanie na negatywną i (lub) brudną kampanię}

Każdy atak na kandydata lub ugrupowanie należy traktować jako sytuację kryzysową. Najważniejsze jest to, że żadna kampania nie jest wolna od negatywnych treści przekazywanych, choćby w formie plotek. Z tego muszą zdać sobie sprawę wszyscy, nawet ci, którzy zakładają prowadzenie tylko pozytywnej kampanii wyborczej.

Pierwszym zadaniem osób kreujących kampanię wyborczą jest stworzenie „czarnej listy, książki” - w języku popularnym jest to tak zwane „wyciaganie trupów z szafy”. Nawet osoby, o których krąży opinia „nieskazitelnych" są narażone na ataki, których podstawą może być np. wydarzenie z życia jego najbliższej lub dalszej rodziny. Stworzenie listy 
zagrożeń jest zadaniem dość trudnym, gdyż wymaga od kandydata pełnego zaufania do osób tworzących kampanię i mających się zajmować reagowaniem na sytuacje kryzysowe. „Czarna książka” powinna także zawierać gotowe scenariusze reagowania na kryzys - dokumenty, zdjęcia, informacje, które będą świadczyć o niesłusznym ataku na kandydata. Jest to bardzo ważne zadanie i należy podejść do niego z dużą odpowiedzialnością. Musimy zdawać sobie sprawę także z tego, że nie jesteśmy w stanie przewidzieć i odnaleźć wszystkich „zapalnych” tematów, którymi możemy być zaatakowani, a także wszystkich dokumentów, które świadczyłby o niewinności kandydata lub grupy kandydatów. Takim przykładem może być przypadek jednego z kandydatów na burmistrza małego miasta $\mathrm{w}$ województwie śląskim, któremu podczas debaty $\mathrm{z}$ kontrkandydatką jedna z osób z widowni wytknęła, że kiedy był harcerzem (miał wtedy 17 lat, a w chwili wyborów miał 35 lat), podobnież zmalwersował pieniądze harcerzy, za co był wydalony z hufca. Informacja była nieprawdziwa, jednak rzucała cień na uczciwość kandydata. Plotkę tę powtarzała osoba, która aktywnie brała udział w kampanii kontrkandydatki. Innym przykładem nieczystych metod dyskredytujących przeciwników była sytuacja z ostatnich wyborów samorządowych. Kandydatce na prezydenta miasta ubiegającej się o reelekcję - matce czwórki dzieci, w tym jednego dziecka z zespołem Dawna zarzucono, że teraz podczas kampanii pokazuje się z dzieckiem wszędzie, żeby wzbudzić litość wśród wyborców, a rzeczywiście dziecko oddała do ośrodka opiekuńczego daleko od miejsca zamieszkania. Informacja była całkowicie nieprawdziwa, ale rozpowszechniana w formie plotki przez sztab konkurenta.

Zanim podejmiemy jakiekolwiek działania zmierzające do wyjaśnienia sytuacji należy bardzo poważnie się zastanowić, czy sytuacja jest warta naszej reakcji, gdyż często polemika może spowodować niepotrzebne zainteresowanie tematem, a w konsekwencji drążenie go i powstawanie na ten temat plotek, które będą krążyć w środowisku wyborców.

Jeśli zdecydujemy się zareagować na nieprawdziwe informacje rozpowszechniane na temat kandydata lub ugrupowania, powinniśmy w tym celu wykorzystać wszelkie możliwe narzędzia komunikacyjne. Jeśli chcemy zakończyć szybko dyskusję na ten temat, najlepszym rozwiązaniem, moim zdaniem, jest oświadczenie podparte dokumentami.

Podstawową zasadą działania w sytuacji kryzysowej jest przekazywanie prawdy. Jeśli rzeczywiście kandydat popełnił błąd, należy się do niego przyznać, podać sytuację, w jakiej do niego doszło i postarać się udowodnić, że nie miało to dużego wpływu na pełnione wcześniej przez 
kandydata stanowisko, ani nie zagroziło konsekwencjami dla innych osób. Jeśli jednak wszystkie te działania zawiodą nie pozostaje nam inne działanie, niż droga sądowa. Kampania wyborcza ma swoje prawa i dzięki temu możemy skorzystać z rozstrzygnięcia pozaprocesowego w tzw. trybie wyborczym, gdzie sąd musi zając się sprawą w ciągu 24 godzin od złożenia pozwu. Nie jestem zwolennikiem prowadzenia kampanii za pomocą sądu, są jednak sytuacje, w których nie ma innej możliwości, aby zmusić kontrkandydata do sprostowania nieprawdziwej informacji i przeproszenia osób poszkodowanych.

\section{Podsumowanie}

Różnica miedzy kampanią negatywną a brudną jest wyraźnie widoczna. W mojej ocenie nie można mechanizmów brudnej kampanii nazwać „czarnym PR”, gdyż jest to coś, co nie istnieje, a żaden członek sztabu wyborczego stosujący takie metody dyskredytowania przeciwników nie powinien nazywać się kimś, kto pracuje jako specjalista public relations. Mam nadzieję, że doczekamy się rzeczywistości, w której każdy, kto będzie prowadził brudną kampanię spotka się z konsekwencjami takiego działania, które będą go eliminowały z tego wspaniałego zawodu, jakim jest komunikowanie społeczne w obszarze polityki oraz z każdej innej dziedziny, gdzie stosuje się narzędzie public relations.

\section{Bibliografia}

Olędzki J., Czarne sztuczki, propaganda i brudny PR, referat wygłoszony na III Kongresie PR w Wyższej Szkole Informatyki i Zarządzania w Rzeszowie, kwiecień 2004.

Mazur M., Marketing polityczny. Wyczerpujacy przeglad technik i metod stosowanych w kampanii wyborczej, Warszawa 2002.

Hope E., Z zagadnień filozofii zarzqdzania i etyki biznesu, Gdańsk 2005.

Trzeciak S., Kampania wyborcza. Strategia sukcesu, Poznań 2002.

Cwalina W., Falkowski A., Marketing polityczny. Perspektywa psychologiczna, GWP, Gdańsk 2006.

$P R$ w ustach polityków. Raport przygotowany na zlecenie Związku Firm Public Relations - styczeń - maj 2009. 


\section{Źródla internetowe:}

http://pl.wikipedia.org/wiki/Czarny_PR.

http://beniowski.salon24.pl/176778,dziadek-z-wehrmachtu-jak-bylo-naprawde.

http://wiadomosci.gazeta.pl/Wiadomosci/1,80708,5854089,Tyminski_W_czarnej_teczce_byly_nieudolne_podrobki.html.

http://palikot.blog.onet.pl/2,ID282457565, index.html.

http://www.spieprzajdziadu.com/muzeum/index.php?title=Antologia_poezji_wolskiej.

http://www.fakt.pl/Palikot-Jaroslaw-gej-a-Lech-alkoholik-,artykuly,55442,1.html.

http://supernowosci24.pl/obalamy-mit-ferenca-jako-dobrego-gospodarza/.

http://www.skupienski.nazwa.pl/blog/wp-content/uploads/2010/12/hz1.jpg.

http://www.wykop.pl/m/artykul/514597/nie-robmy-polityki-lepmy-pierogi/.

http://lista-obecnosci.blogspot.com/2007_09_30_archive.html.

http://yarrok.blogspot.com/2009/03/kolejny-eurowyborczy-hit-platformy.html.

\section{A negative campaign, or the non-existence of 'black PR,' as a method to discredit a political opponent}

\section{Summary}

The difference between a negative campaign and a dirty one is clearly defined. The mechanisms of a dirty campaign cannot be named 'black PR' as this does not exist and any member of an election committee who employs such methods to discredit their opponents should not be called a public relations specialist at all. It is to be hoped that we will see a reality where anybody running a dirty campaign will bear the consequences of their activities and be eliminated from the ranks of this magnificent profession dealing with social communication in politics, and from any other activity applying PR tools. 